\title{
AUTENTIKASI CEPAT MADU HUTAN KALIMATAN TIMUR DENGAN ATR-FTIR SPEKTROSKOPI KOMBINASI ANALISIS KEMOMETRIKA
}

\author{
[Fast Authentication of Honey from East Kalimantan Forest using \\ ATR-FTIR and Chemometrics]
}

\section{Yudha Agus Prayitno'), Aswita Emmawati' ${ }^{2)}$, Sulistyo Prabowo ${ }^{2)}$, Krishna Purnawan Candra') dan Anton Rahmadi ${ }^{2,3)_{\star}}$ \\ 1) Program Studi Magister Pertanian Tropika Basah, Fakultas Pertanian, Universitas Mulawarman, Samarinda \\ 2) Program Studi Teknologi Hasil Pertanian, Fakultas Pertanian, Universitas Mulawarman, Samarinda \\ 3) PUI-PT Oktal, Universitas Mulawarman, Samarinda}

Diterima 16 Juni 2020 / Disetujui 11 Desember 2021

\begin{abstract}
Honey adulteration is mostly conducted by the addition of sucrose. In this study, the authentication of honey was conducted using ATR-FTIR and chemometrics. Pure honey samples (MA) were collected from nine regions in East Kalimantan. The ATR-FTIR spectra of these samples were then compared to sucroseadulterated honey (MS), which were prepared in the sucrose concentration from 2.5 to $50 \%(\mathrm{~V} / \mathrm{v})$. The data analysis was performed using chemometrics techniques: 1) Principle Component Analysis (PCA) method, 2) classification with Discriminant Analysis (DA), and 3) regression with (PCR) and (PLS). As a result, PCA was able to visualize the differences between MS and MA. DA analysis was able to distinguish MS and MA at wave numbers from 1200 to $800 \mathrm{~cm}^{-1}$ with $92.5 \%$ performance index. Quantitative calibration models of the sucrose-adulterated honey could be obtained from PLS and PCR, while the best calibration model was obtained with the PLS method from the $2^{\text {nd }}$ derivative spectra. In summary, sucroseadulterated honey from East Kalimantan can be authenticated using ATR-FTIR method in combination with chemometric analysis.
\end{abstract}

Keywords: adulteration, ATR-FTIR, chemometrics, honey, sucrose

\begin{abstract}
ABSTRAK
Kasus pemalsuan madu umumnya diidentifikasi dengan penambahan sukrosa. Dalam penelitian ini, analisis autentikasi madu dilakukan menggunakan instrumen ATR-FTIR dan kemometrika. Madu asli (MA) diperoleh dari sembilan wilayah di Kalimantan Timur dan dibandingkan dengan madu yang telah diadulterasi dengan sukrosa (MS) pada rentang konsentrasi penambahan sukrosa 2,5-50\% (v/v). Analisis lanjutan dilakukan dengan teknik kemometrika: 1) Principle Component Analysis (PCA), 2) klasifikasi dengan Discriminat Analysis (DA), dan 3) regresi dengan Principle Component Regression (PCR) dan Partial Least Square (PLS). Hasilnya, PCA mampu memvisualisasikan perbedaan antara MS dan MA. DA mampu membedakan MS dan MA pada bilangan gelombang $1200-800 \mathrm{~cm}^{-1}$ dengan performance index 92,5\%. Model kalibrasi kuantitatif dapat diperoleh dari PLS dan PCR dengan model kalibrasi terbaik didapatkan pada metode PLS berdasarkan spektra $2^{\text {nd }}$ derivative. Sebagai kesimpulan, madu Kalimantan Timur yang diadulterasi dengan sukrosa dapat di otentikasi dengan metode ATR-FTIR yang dikombinasikan dengan analisis kemometrika.
\end{abstract}

Kata kunci: adulterasi, ATR-FTIR, kemometrika, madu, sukrosa

\footnotetext{
*Penulis Korespondensi: E-mail: arahmadi@unmul.ac.id
} 


\section{PENDAHULUAN}

Madu memiliki peran sebagai pangan Madu juga sering dikonsumsi sebagai sumber antioksidan (Cengiz dan Durak, 2019). Masyarakat berpendapat bahwa madu hutan lebih baik dibandingkan madu dari lebah ternak, oleh sebab sumber polen yang beragam. Persepsi tersebut menyebabkan harga madu hutan lebah alami jauh lebih mahal dibandingkan dengan harga madu lebah ternak pada umumnya. Oleh karenanya, madu hutan rawan dipalsukan (Huang et al., 2020). Berbagai kasus pemalsuan yang telah diidentifikasi melibatkan penambahan sukrosa (Li et al., 2016).

Saat ini diperlukan cara deteksi pemalsuan madu dengan cepat dan akurat. Deteksi pemalsuan/ pengoplosan madu dapat dilakukan dengan analisis kadar sukrosa menggunakan teknik kromatografi HPLC dan GC. Saat ini telah pula dikembangkan deteksi pemalsuan/pengoplosan madu menggunakan metode spektroskopi Infra Merah (FTIR) yang dikombinasikan dengan kemometrika dan analisis multivariat. Analisis ini memerlukan persiapan bahan yang lebih minimal, mudah dan cepat (Huang et al., 2020). Analisis multivariat yang digunakan adalah principal component analysis (PCA), partial leastsquare (PLS), principle component regression (PCR), dan discriminant analysis (DA) (Fechner et al., 2020).

Penggunaan FTIR yang dikombinasikan dengan kemometrika untuk pendeteksian keaslian produk telah banyak dilaporkan, misalnya untuk minyak alpukat (Lumakso et al., 2015), minyak zaitun murni (Rohman et al., 2014), adulterasi daging tikus (Pebriana et al., 2017), penambahan daging babi bakso (Rohman et al., 2011), deteksi gelatin babi pada permen jelly (Rahmawati et al., 2015). PeneItian lain tentang adulterasi menggunakan sukrosa dilaporkan oleh (Riswahyuli et al., 2020) tentang pemalsuan madu hutan dengan konsentrasi kadar sukrosa $10-50 \%$. Pada saat ini belum ada publikasi tentang metode pendekatan otentikasi keaslian madu hutan dari Kalimantan Timur menggunakan kombinasi FTIR spektra dan analisis kemometrika. Pada penelitian ini dilakukan validitas kombinasi metode spektra FTIR dan analisis kemometrika untuk pengujian keaslian madu menggunakan sembilan madu hutan asal Kalimantan Timur.

\section{BAHAN DAN METODE}

\section{Bahan}

Sampel madu lebah hutan diperoleh dari sembilan daerah di tiga kabupaten di Kalimantan Timur, yaitu kawasan Goa Parung, Goa Tembenus dan Hutan Konservasi ITCI di Kabupaten Penajam Paser Utara; Kawasan Bongan, Long Bagun dan
Muara Lawa di Kabupaten Kutai Barat; kawasan Bukit Bengkirai, Muara Bengkal dan Lebak Cilong di Kabupaten Kutai Kartanegara. Sukrosa yang digunakan sebagai adulteran diperoleh dari Pudak, Indonesia.

\section{Persiapan bahan}

Sampel madu adulterasi disiapkan dengan cara memasukkan madu pada botol vial dan menambahkan sukrosa dengan level tingkat pemalsuan pada konsentrasi 2,$5 ; 5 ; 7,5 ; 10 ; 12,5 ; 15 ; 17,5 ; 20$; 22,$5 ; 25 ; 27,5 ; 30 ; 32,5 ; 35 ; 37,5 ; 40 ; 42,5 ; 45,47,5$; dan $50 \%$ dengan 3 kali ulangan, kemudian memanaskannya dalam air pada suhu $50^{\circ} \mathrm{C}$ untuk melarutkan kristal gula secara homogen, kemudian didinginkan dan disimpan pada suhu ruang $\left(28 \pm 3^{\circ} \mathrm{C}\right)$.

\section{Analisis attenuated total reflectance fourier transformed infra-red (ATR-FTIR) (Rohman et al., 2014)}

Pengukuran madu dengan ATR-FTIR menggunakan Thermo Nicolet 6700 (Thermo Nicolet Corp, Madison, WI, USA), dengan lempeng kristal ZnSe, dengan teknik pembacaan attenuated total reflectance (ATR). Spektra ATR-FTIR dibaca dengan software Nicolet Omnic (version 7.0, Thermo Nicolet). Madu yang sebelumnya telah diadulterasi dengan cara dicampur dengan berbagai konsentrasi sukrosa diletakkan pada kristal ZnSe pada suhu $\left(24 \pm 2^{\circ} \mathrm{C}\right)$. Pengukuran sebanyak 32 kali pembacaan (scanning) pada (resolution) $4 \mathrm{~cm}^{-1}$ dan selanjutnya dilakukan pembilasan pada lempeng kristal ZnSe dengan $n$-heksana dan aseton, dilanjutkan dengan pengeringan menggunakan tissue halus. Semua spektra direkam pada bilangan gelombang antara 4000 sampai $650 \mathrm{~cm}^{-1}$ dengan tiga kali replikasi, sehingga didapatkan 60 data spektra madu yang dengan sengaja telah diadulterasi. Penelitan kemudian difokuskan pada bilangan gelombang antara 1200 dan $800 \mathrm{~cm}^{-1}$ dengan menghitung nilai absorbansi. Hasil pembacaannya digolongkan ke dalam dua wilayah spektra, yaitu wilayah spektra kelompok fungsional $4000-1500 \mathrm{~cm}^{-1}$ dan wilayah spektra sidik jari 1500-650 $\mathrm{cm}^{-1}$ (Matwijczuk et al., 2019). Tahap selanjutnya, data visual diinterpretasikan dengan perangkat lunak OMNIC (Thermo Fisher, USA).

\section{Analisis kemometrika}

Analisis kemometrik dilakukan menggunakan software TQ Analyst 9.0 (Thermo Nicolet, Madison, WI, USA) berdasarkan data spektra ATR-FTIR yang diperoleh. Analisis ini diawali dengan melakukan analisis komponen utama (Principle Component Analysis, PCA) dilanjutkan dengan analisis diskriminan (Discriminant Analysis, DA) untuk menentukan jenis sampel berdasarkan lebih dari satu variabel bebas. PCA digunakan untuk evaluasi awal struktur data, yaitu deteksi dan diferensiasi sampel secara 
dini (pengurangan jumlah variabel). Plot skor analisis komponen prinsip pertama (PC1) dan komponen prinsip kedua (PC2) diperoleh pada bilangan gelombang $4000-650 \mathrm{~cm}^{-1}$ untuk selanjutnya ditentukan sebagai variabel dalam analisis. Lohumi et al. (2015) menerangkan bahwa kemometrik PCA digunakan untuk menentukan komponen prinsip yang paling berpengaruh sehingga dapat digunakan sebagai teknik pengelompokkan atau diferensiasi sampel PCA menghasilkan plot score yang kemudian digunakan sebagai data untuk mengelompokkan madu asli dan madu yang telah di adulterasi dengan sukrosa melalui penghitungan jarak Mahalanobis menggunakan DA (Rohman et al., 2014). Wilayah bilangan gelombang yang profil spektrumnya berbeda secara signifikan dipilih sebagai model kalibrasi. Tingkat adulterasi (kandungan) sukrosa dianalisis dengan regresi menggunakan partial least square dan partial component regression. Nilai root mean square error of calibration (RMSEC), root mean square error of prediction (RMSEP) dan koefisien determinasi $\left(R^{2}\right)$ digunakan untuk menentukan model kalibrasi yang tepat.

\section{HASIL DAN PEMBAHASAN}

\section{Spektra ATR-FTIR Madu}

Salah satu faktor yang membedakan MA dengan madu yang telah dipalsukan adalah perbedaan kadar gula, misalnya penambahan sukrosa (Cengiz dan Durak, 2019). Penambahan gula tidak mengubah tampilan fisik dari madu. Metode deteksi cepat dengan ATR-FTIR dapat membedakan antara MA dan MS baik pada konsentrasi pekat maupun cair (Gan et al., 2016). Spektrum madu asli (MA) diukur pada panjang gelombang $4000-650 \mathrm{~cm}^{-1}$ dan dibandingkan dengan standar gula sukrosa (Gambar 1), Pada spektrum yang dihasilkan oleh standar sukrosa terdapat zona serapan yang mirip pada madu pada bilangan gelombang antara daerah sidik jari $1500-650 \mathrm{~cm}^{-1}$.

Spektrum madu asli (MA) dan madu sukrosa (MS) pada panjang gelombang $4000-650 \mathrm{~cm}^{-1}$ dapat dilihat pada Gambar 2. Terdapat empat zona serapan yang didominasi oleh dua puncak pada bilangan gelombang $3286 \mathrm{~cm}^{-1}$ (peregangan $\mathrm{OH}$ ) dan $1642 \mathrm{~cm}^{-1}$ (deformasi OH). Selanjutnya, puncak terdapat pada bilangan gelombang $2933 \mathrm{~cm}^{-1}$ peregangan $\mathrm{C}-\mathrm{H}$ (asam karboksilat) dan peregangan $\mathrm{NH}_{3}$ yang bersumber dari asam amino bebas. Kedua senyawa ini terdapat dalam madu pada konsentrasi rendah dan tidak dipertimbangkan dalam model ini. Terdapat perbedaan spektral antara MA dan MS pada bilangan gelombang antara 1200$800 \mathrm{~cm}^{-1}$ (Gambar 3). Gok et al. (2015) melaporkan penelitian serupa pada madu anatolia yang berasal dari Turki. Pada penelitiannya, spektra sampel madu didiferensiasi pada wilayah $1400-750 \mathrm{~cm}^{-1}$. Puncakpuncak pada bilangan gelombang 1500 hingga 750 $\mathrm{cm}^{-1}$ merupakan daerah serapan paling sensitif, khususnya gula madu. Sukrosa, glukosa, fruktosa, terdeteksi pada panjang gelom-bang antara 1500$900 \mathrm{~cm}^{-1}$. Wilayah spektral yang terdapat pada wilayah $900-750 \mathrm{~cm}^{-1}$ adalah ciri khas dari beberapa jenis sakarida (Cengiz dan Durak, 2019).

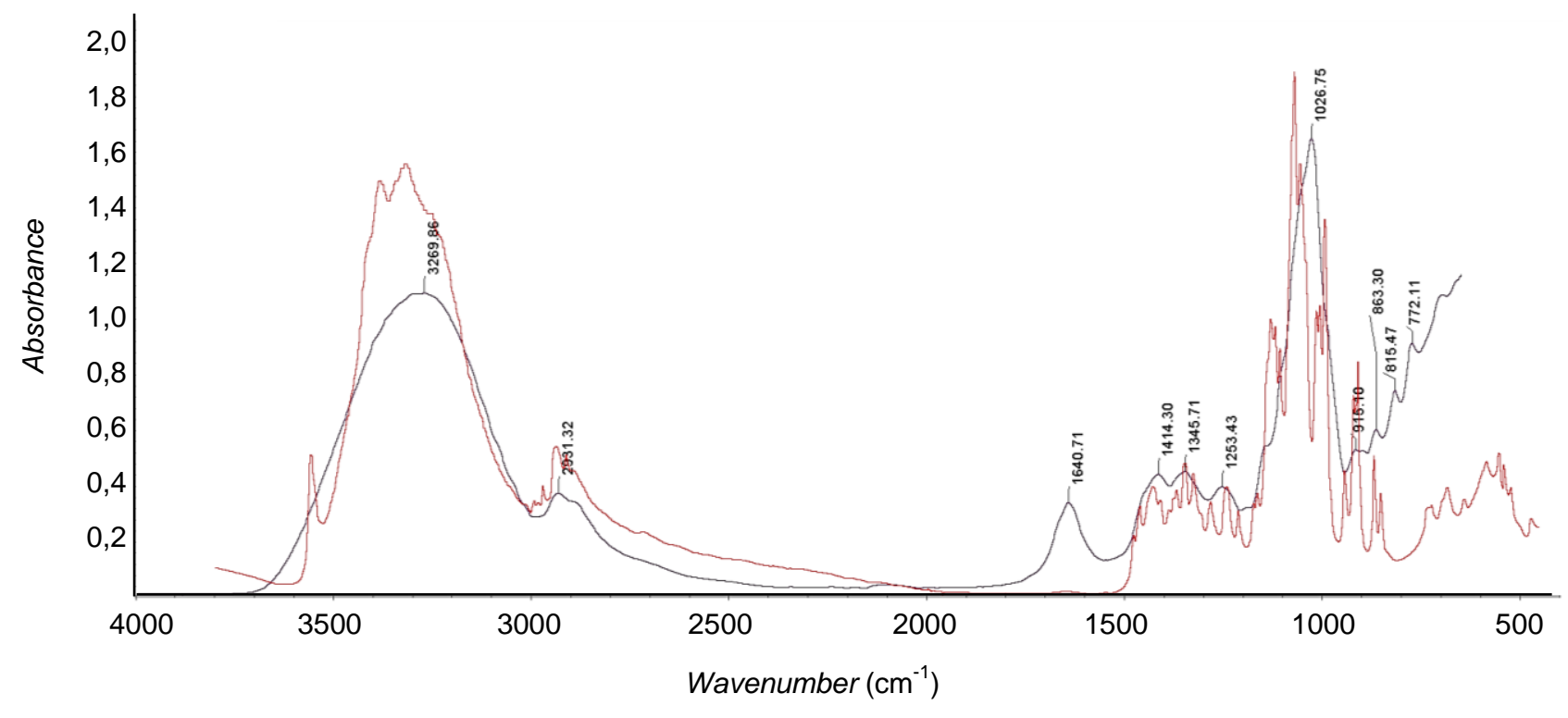

Keterangan: $\longrightarrow=$ Madu asli; $\longrightarrow=$ Madu sukrosa

Gambar 1. Spektrum ATR-FTIR madu asli (MA) dan standar sukrosa pada bilangan gelombang 4.000$650 \mathrm{~cm}^{-1}$ 

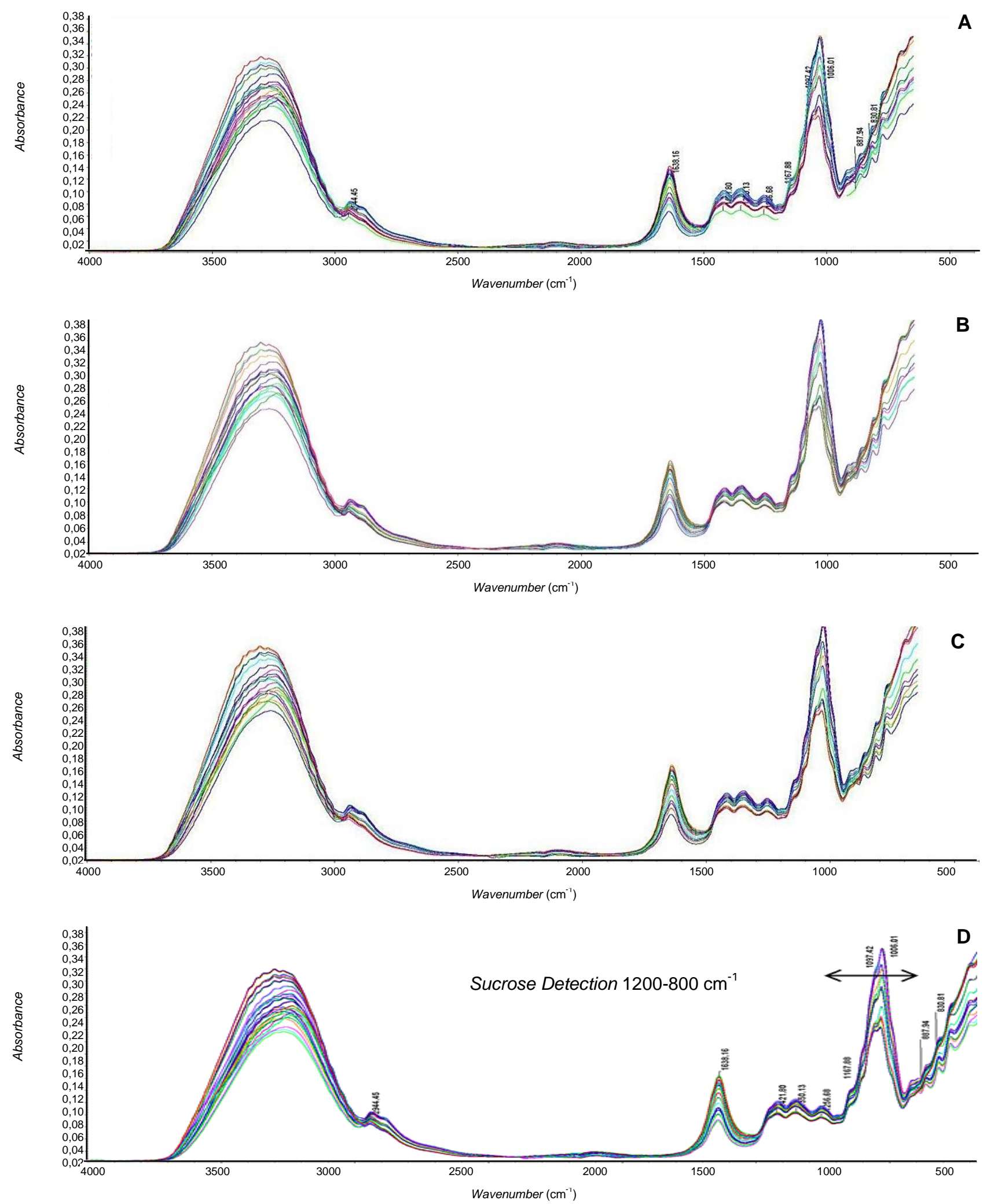

Gambar 2. Spektrum ATR-FTIR biner campuran madu asli (MA) dan sukrosa (MS) Ulangan 1 (A) Ulangan 2 (B) Ulangan 3 (C) Semua Spektrum (D) pada bilangan gelombang $4.000-650 \mathrm{~cm}^{-1}$ 


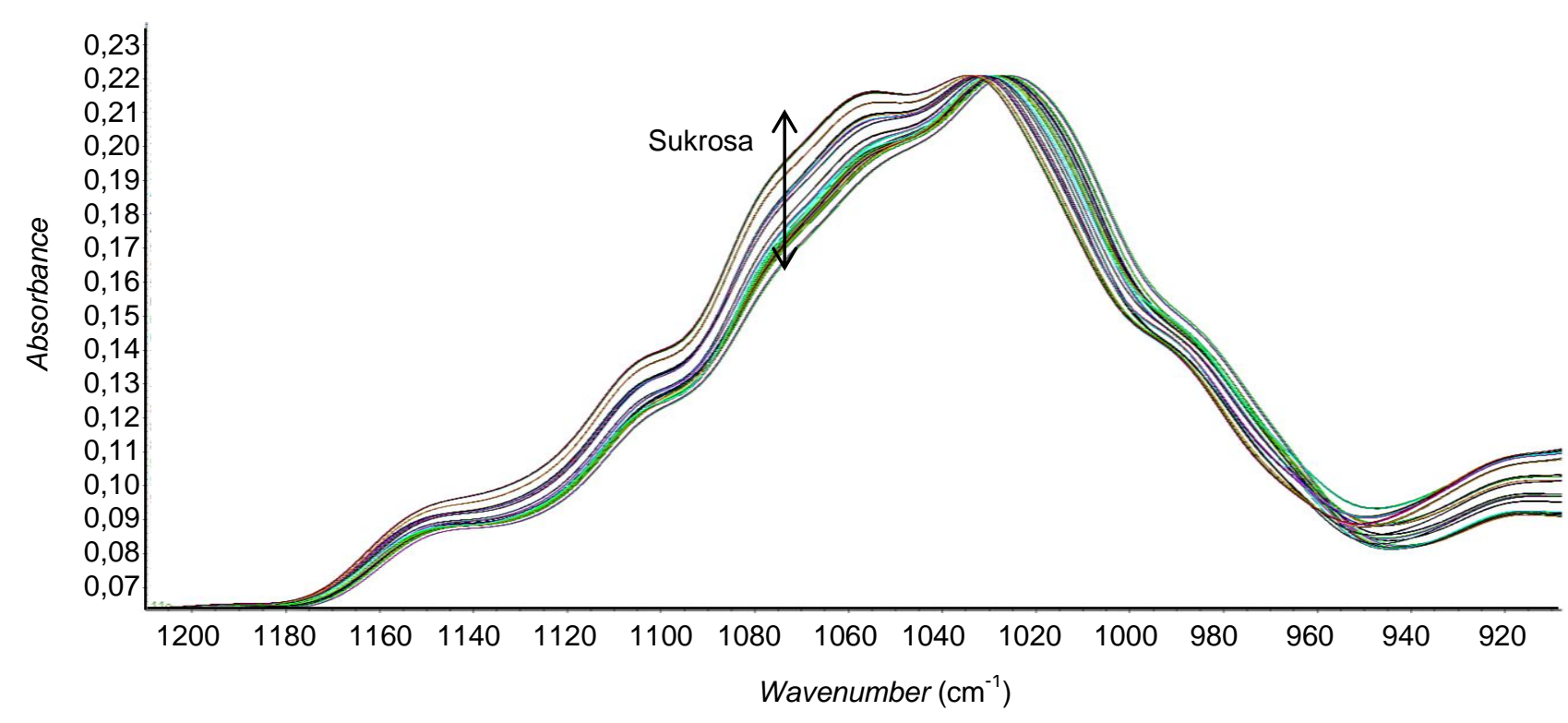

Gambar 3. Semua Spektrum ATR-FTIR biner campuran madu asli (MA) dan madu sukrosa (MS) pada bilangan gelombang $1200-800 \mathrm{~cm}^{-1}$

\section{Principle component analysis}

Principle Component Analysis (PCA) merupakan salah satu metode kemometrik yang sering digunakan untuk memungkinkan proyeksi data dari dimensi yang paling tinggi dan paling rendah. PCA didasarkan pada varians data yang dipecah menjadi sejumlah kecil prinsipal komponen (PC) melalui transformasi matematika. PC pertama menjelaskan informasi maksimum dari data dan setiap PC berturut-turut menggambarkan jumlah maksimum varians residual. Pada penyelidikan awal PCA pada penelitian ini digunakan untuk membedakan MA dengan MS. Dalam proses PCA, variabel awal direduksi menjadi sejumlah variabel komponen utama. Seperti yang ditunjukkan pada Gambar 4, hasil spektra ATR-FTIR pada wilayah bilangan gelombang 4.000-650 $\mathrm{cm}^{-1}$ menunjukkan adanya tiga komponen utama, yaitu PC1, PC2, dan PC3 dengan nilai varian berturut-turut sebesar 85,$31 ; 13,75$; dan $0,51 \%$. PCA digunakan untuk menentukan komponen prinsip yang paling berpengaruh sehingga dapat digunakan sebagai teknik pengelompokkan atau diferensiasi sampel. Akan tetapi, hasil plot score PCA yang diperoleh belum mampu dimanfaatkan untuk kuantifikasi perbedaan antara MA dan MS. Menurut Rohman et al. (2014), PCA digunakan untuk evaluasi awal struktur data, karena hasilnya tidak dapat dikuantifikasi dengan baik. Oleh karena itu analisis perlu dilanjutkan dengan teknik Multivariate Recognition, salah satunya dengan Discriminat Analisis.

\section{Discriminant analysis}

Discriminant Analysis (DA) digunakan untuk membedakan antara madu sukrosa (MS) dan madu asli (MA) berdasarkan jarak Mahalanobis. Hasil DA diperoleh MA terpisah dengan MS dengan tingkat akurasi $99,93 \%$ dengan performance index $92,50 \%$ dalam rentang jarak mahalanobis MA 0,550-3,905 dan MS 0,484-3,792 untuk setiap sampel. Tidak ada sampel MS dan MA yang tercampur dalam proses pengelompokkan. Menurut Rohman et al. (2014) analisis ini secara umum digunakan untuk pengelompokkan antara sampel autentik dan sampel tercemar. Variabel yang digunakan DA adalah absorbansi di seluruh bilangan gelombang dengan jarak Mahalanobis dan dihitung berdasarkan intensitas absorbansi (Ballabio et al., 2018). Analisis ini menggunakan model alogaritma berbasis PCA untuk maksimum 10 principal component (PC). Pemilihan PC dilakukan berdasarkan pola jarak antara pusatpusat kluster dan spektrum sampel, atau dikenal sebagai jarak Mahalanobis (Rohman et al., 2014). Gambar 5 menunjukkan plot coomans untuk pengelompokkan antara MA dan MS. Sumbu x merupakan jarak mahalonobis MA sementara sumbu y merupakan jarak mahalanobis MS sehingga disimpulkan bahwa plot coomans dapat digunakan untuk tujuan klasifikasi madu yang diadulterasi. Pengelompokkan ini dilakukan pada bilangan antara 1200 dan 800 $\mathrm{cm}^{-1}$, seperti yang dilakukan pada penelitian Zhou et al. (2014). Madu Anatolia memiliki diferensiasi terbaik pada bilangan gelombang mulai 1800 hingga $750 \mathrm{~cm}^{-1}$ (Gok et al., 2015). Bilangan gelombang $1500-800 \mathrm{~cm}^{-1}$ akan mencakup sebagian besar karakteristik pita serapan yang relevan dengan gula seperti fruktosa, sukrosa, dan glukosa (Wang et al., 2010). Anomer dari gula umumnya diserap pada bilangan gelombang 950 hingga $750 \mathrm{~cm}^{-1}$ (Anjos et al., 2015). 


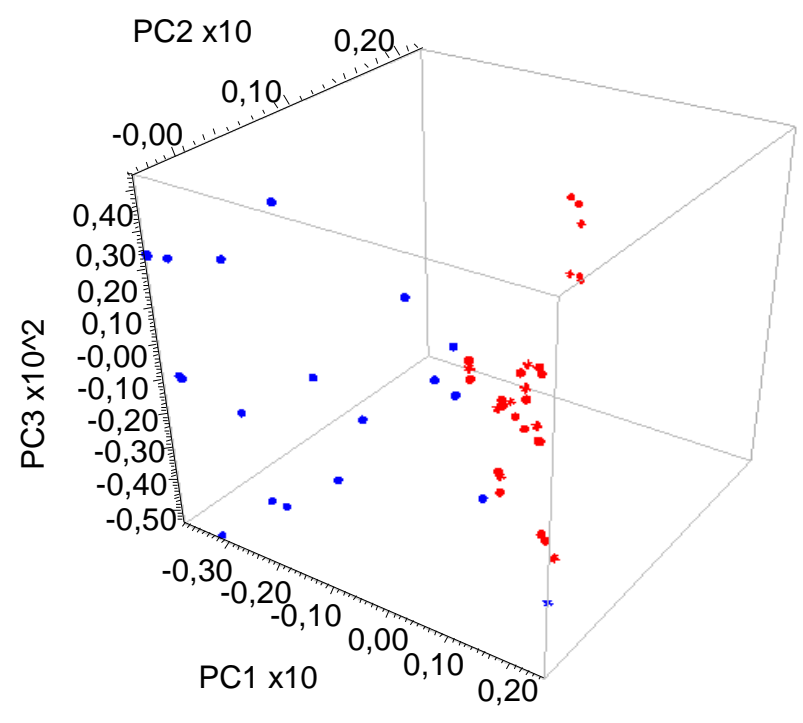

Keterangan: Sampel madu asli $(\mathrm{MA})=$ warna merah; Madu yang di adulterasi dengan $2,5-50 \%$ sukrosa $(M S)=$ warna biru

Gambar 4. Skor komponen utama PCA dengan proyeksi 3D

\section{Analisis kuantitatif dengan principle component} regression (PCR) dan partial least square (PLS)

Analisis kuantitatif sukrosa dalam madu dilakukan dengan model dua kalibrasi multivariat PCR dan PLS. Model ini dapat digunakan untuk memprediksi adanya adulteran sukrosa pada madu. Teknik ini biasa digunakan pada analisis campuran yang kompleks. Teknik ini dapat menentukan setiap komponen dari setiap campuran yang terdapat dalam bahan secara cepat dalam waktu yang singkat (Quiñones-Islas et al., 2013). Kisaran bilangan gelombang pada analisis kuantitatif pada penelitian ini antara 1200-800 cm $\mathrm{cm}^{-1}$. Tabel 1 menginformasikan hasil kalibrasi PCR dan PLS untuk adulteran sukrosa dalam madu baik dengan spektra normal, spektra turunan pertama $\left(1^{\text {st }}\right.$ derivative spectra), dan spektra turunan kedua $\left(2^{\text {nd }}\right.$ derivative spectra). Secara teori, pencitraan spektroskopi FT-IR memungkinkan tersajinya informasi komposisi spasial yang menunjukkan spesifisitas untuk senyawa tertentu. Namun, analisis data spektroskopi FT-IR tidak selalu efisien, karena boleh jadi terdapat tumpang tindih penyerapan spektrum inframerah antar berbagai molekul. Spesifisitas molekuler spektroskopi FT-IR sepenuhnya ditentukan oleh metode analisis data spektral. Spektra turunan $\left(1^{\text {st }}\right.$ dan $2^{\text {nd }}$ derivative $)$ memungkinkan identifikasi yang lebih spesifik dan belum tersajikan pada spectra normal. Cara derivasi spektra ini digunakan untuk meningkatkan kekhususan deteksi puncak penyerapan molekul tertentu dari bahan yang akan dianalisis (Rieppo et al., 2012).

Rentang root mean square error calibration (RMSEC) pada model kalibarasi PLS dan PCR terdapat di antara 0,0057 dan 0,0133\% v/v dengan nilai $R^{2} \quad 0,9958-0,9992$. Rentang root mean square error prediction (RMSEP) berada di antara 0,9920 dan $0,9934 \% \mathrm{v} / \mathrm{v}$ dengan nilai $\mathrm{R}^{2}$ 0,0197-0,0127. Perhitungan PLS pada spektra $2^{\text {nd }}$ derivative memberikan hasil yang lebih baik dilihat dari nilai RMSEP $0,0127 \% \mathrm{v} / \mathrm{v}\left(\mathrm{R}^{2} 0,9965\right)$ dan RMSEC $0,0057 \% \mathrm{v} / \mathrm{v}$ $\left(R^{2} 0,9992\right)$. Root mean square error (RMSE), terdiri dari RMSEC dan RMSEP, adalah nilai kesalahan dalam model, jika semakin kecil nilai RMSE, maka akan semakin baik model kalibrasi. Nilai $R^{2}$ menunjukkan seberapa dekat hubungan antara nilai nyata dengan nilai prediksi dari instrumen yang digunakan (Rohman et al., 2014). Apabila nilai $R^{2}$ semakin mendekati angka 1, maka model kalibrasi semakin baik.

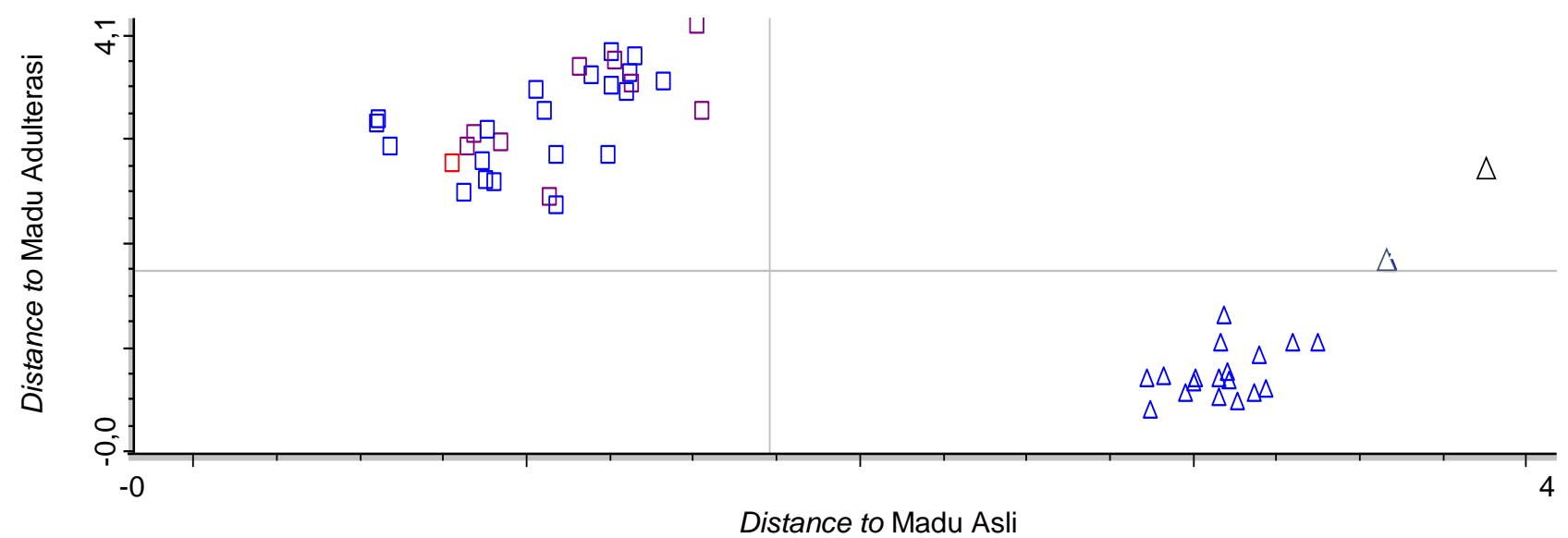

Keterangan: $\square=\mathrm{X}$ calibration; $\square=\mathrm{X}$ validation; $\Delta=\mathrm{Y}$ calibration; $\Delta=\mathrm{Y}$ validation; $\mathrm{O}=$ Other calibration; $O=$ Other validation; $\otimes=$ Ignore

Gambar 5. Pengelompokkan madu asli ( $\square$ ) dan madu adulterasi $2,5-50 \%$ sukrosa $(\Delta)$ dengan plot Coomans 
Gambar 6 memperlihatkan plot sebaran antara actual value kandungan sukrosa sumbu (x) dan kandungan sukrosa terprediksi dengan ATR-FTIR sumbu (y) pada spektra $2^{\text {nd }}$ derivative pada model PLS. Hasil yang diperoleh dapat dilihat bahwa kalibrasi dengan model PLS lebih baik dibandingkan model PCR dilihat dari perbedaan nilai RMSEC dan
RMSEP. Berdasarkan hasil DA dan PLS, spektroskopi ATR-FTIR adalah teknik yang reliabel dan akurat pada deteksi kandungan sukrosa dalam madu. Hal ini terlihat dari tingginya nilai koefesien determinasi $\left(R^{2}\right)$ serta nilai kesalahan yang rendah, baik kesalahan dikalibrasi (RMSEC) maupun kesalahan diprediksi yang dinyatakan sebagai (RMSEP).

Tabel 1. Kalibrasi multivariat untuk menentukan kandungan sukrosa dalam madu pada bilangan gelombang $1200-800 \mathrm{~cm}^{-1}$ dengan menggunakan teknik PLS dan PCR

\begin{tabular}{|c|c|c|c|c|c|}
\hline \multirow{2}{*}{ Metode Analisis Multivariat } & \multirow{2}{*}{ Jenis Spektra } & \multicolumn{2}{|c|}{ Kalibrasi } & \multicolumn{2}{|c|}{ Validasi } \\
\hline & & $R^{2}$ & RMSEC & $\mathrm{R}^{2}$ & RMSEP \\
\hline \multirow[t]{3}{*}{ Partial least square } & Normal & 0,9981 & 0,0089 & 0,9934 & 0,0169 \\
\hline & Turunan pertama & 0,9975 & 0,0102 & 0,9920 & 0,0182 \\
\hline & Turunan kedua & 0,9992 & 0,0057 & 0,9965 & 0,0127 \\
\hline \multirow[t]{3}{*}{ Principle component regression } & Normal & 0,9965 & 0,0122 & 0,9914 & 0,0191 \\
\hline & Turunan pertama & 0,9974 & 0,0104 & 0,9919 & 0,0184 \\
\hline & Turunan kedua & 0,9958 & 0,0133 & 0,9920 & 0,0184 \\
\hline
\end{tabular}

Keterangan: Spektra ATR-FTIR pada diperoleh pada bilangan gelombang $1.200-800 \mathrm{~cm}^{-1}$; RMSEC $=$ root mean square error of calibration; RMSEP= root mean square error of prediction
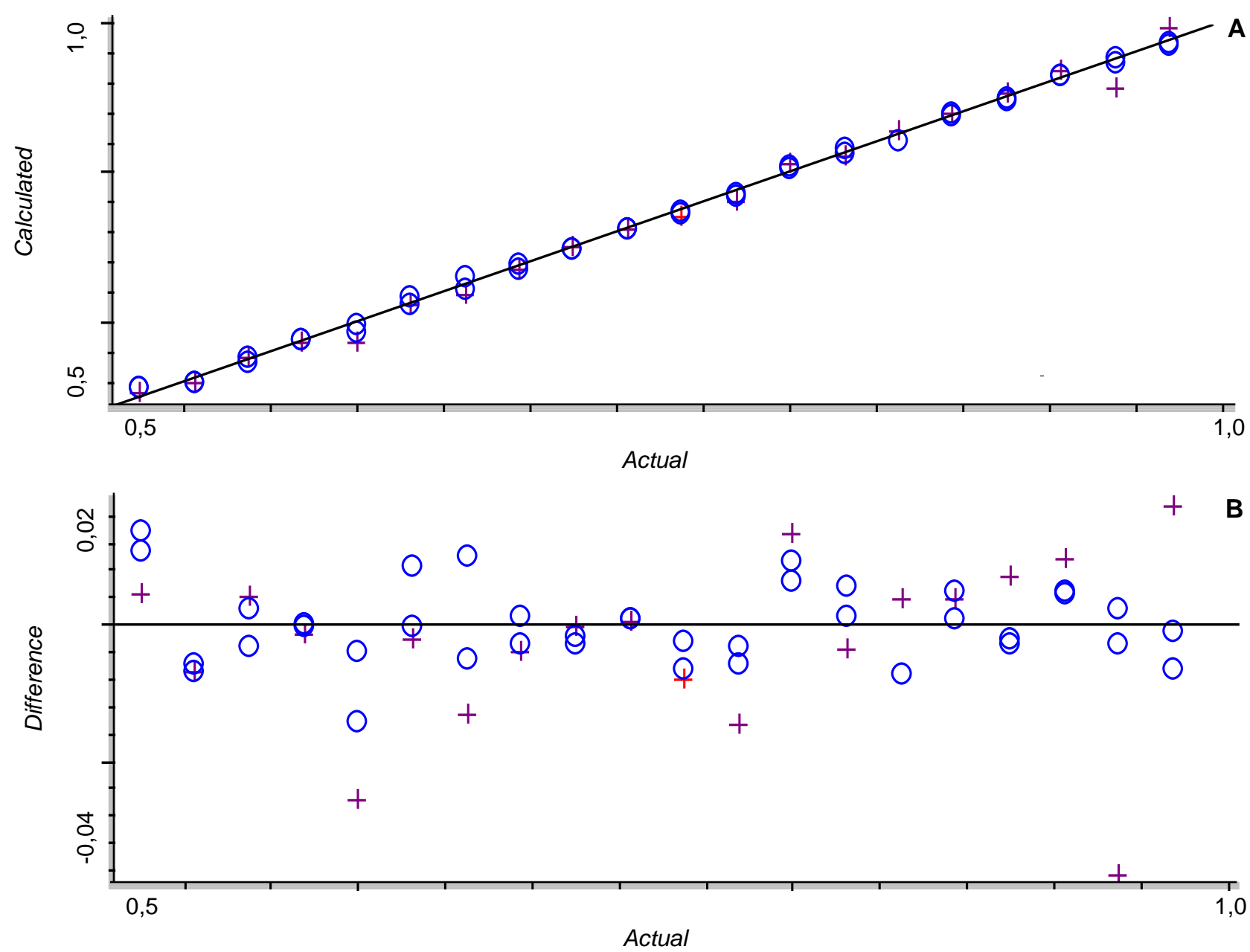

Keterangan: $O=$ Calibration; $+=$ Validation; $\Delta=$ Correction; $\square=$ Cross-correction; $\propto=$ Ignore

Gambar 6. Hubungan antara nilai aktual (sumbu $\mathrm{x}$ ) dan nilai prediksi (sumbu y) sukrosa dalam madu (A) serta analisis residual (B) pada model kalibrasi PLS derivat ke-2 


\section{KESIMPULAN}

Penggunaan ATR-FTIR dengan teknik kemometrik dan multivariate dapat digunakan untuk membedakan antara madu asli (MA) dan madu sukrosa (MS). Metode ini dapat digunakan sebagai acuan pengujian pemalsuan madu dengan cara cepat khususnya untuk mengidentifikasi pemalsuan madu dengan penambahan gula. Visualisasi madu metode PCA belum dikuantifikasi, sehingga perlu dilanjutkan dengan DA. Metode DA dapat mengklasifikasikan madu asli dan palsu dengan perbedaan jarak Mahalanobis pada performance index sebesar 92,50\%. Model regresi linier kuantifikasi adulterasi sukrosa pada madu hutan asal Kalimantan Timur dapat dikembangkan menggunakan PLS dengan nilai $R^{2}$ mendekati angka 1 pada spektra normal, $1^{\text {st }}$ derivative, dan $2^{\text {nd }}$ derivative. Model kalibrasi PLS terbaik terdapat pada spektra $2^{\text {nd }}$ derivative dengan $R^{2} 0,9992$ untuk RMSEC $0,0057 \% v / v$ dan $R^{2} 0,9965$ untuk RMSEP $0,0127 \% \mathrm{v} / \mathrm{v}$.

\section{UCAPAN TERIMA KASIH}

Terima kasih kepada LPPT UGM atas bantuan fasilitas dalam penelitian ini. Sebagian riset ini didanai Toray Indonesia tahun 2020.

\section{DAFTAR PUSTAKA}

Anjos O, Campos MG, Ruiz PC, Antunes P. 2015. Application of FTIR-ATR spectroscopy to the quantification of sugar in honey. Food Chem 169: 218-223. DOI: 10.1016/j.foodchem.2014. 07.138 .

Ballabio D, Robotti E, Grisoni F, Quasso F, Bobba M, Vercelli S, Gosetti F, Calabrese G, Sangiorgi E, Orlandi M, Marengo E. 2018. Chemical profiling and multivariate data fusion methods for the identification of the botanical origin of honey. Food Chem 266: 79-89. DOI: 10.1016/j. foodchem.2018.05.084.

Cengiz MF, Durak MZ. 2019. Rapid detection of sucrose adulteration in honey using Fourier transform infrared spectroscopy. Spectrosc Lett 52: 267-273. DOI: 10.1080/00387010.2019.161 5957.

Fechner DC, Hidalgo MJ, Díaz JDR, Gil RA, Pellerano RG. 2020. Geographical origin authentication of honey produced in Argentina. Food Biosci 33: 1-8. DOI: 10.1016/j.fbio.2019. 100483.

Gan Z, Yang Y, Li J, Wen X, Zhu M, Jiang Y, Ni Y. 2016. Using sensor and spectral analysis to classify botanical origin and determine adulteration of raw honey. J Food Eng 178: 151-158. DOI: 10.1016/j.jfoodeng.2016.01.016.

Gok S, Severcan M, Goormaghtigh E, Kandemir I, Severcan F. 2015. Differentiation of anatolian honey samples from different botanical origins by ATR-FTIR spectroscopy using multivariate analysis. Food Chem 170: 234-240. DOI: 10. 1016/j.foodchem.2014.08.040.

Huang F, Song H, Guo L, Guang P, Yang X, Li L, Zhao H, Yang M. 2020. Detection of adulteration in Chinese honey using NIR and ATR-FTIR spectral data fusion. Spectrochim Acta A 235: 118297. DOI: 10.1016/j.saa.2020.118297.

Li S, Zhang X, Shan Y, Su D, Ma Q, Wen R, Li J. 2016. Qualitative and quantitative detection of honey adulterated with high-fructose corn syrup and maltose syrup by using near-infrared spectroscopy. Food Chem 218: 231-236. DOI: 10.10 16/j.foodchem.2016.08.105.

Lohumi S, Lee S, Lee H, Cho BK. 2015. A review of vibrational spectroscopic techniques for the detection of food authenticity and adulteration. Trends Food Sci Technol 46: 85-98. DOI: 10.10 16/j.tifs.2015.08.003.

Lumakso FA, Riyanto S, Ahmad SAS, Rosman AS, Yusoff FM, Rohman A. 2015. Application of chemometrics in combination with fourier transform mid infrared spectroscopy for authentication of avocado oil. J Food Pharm Sci 3: 12-17.

Matwijczuk A, Oniszczuk T, Matwijczuk A, Chruściel E, Kocira A, Niemczynowicz A, Wójtowicz A, Combrzyński M, Wiacek D. 2019. Use of FTIR spectroscopy and chemometrics with respect to storage conditions of Moldavian Dragonhead Oil. Sustainability 11: 1-16. DOI: 10.3390/su11 226414.

Pebriana RB, Rohman A, Lukitaningsih E, Sudjadi. 2017. Development of FTIR spectroscopy in combination with chemometrics for analysis of rat meat in beef sausage employing three lipid extraction systems. Int J Food Prop 20: 19952005. DOI: 10.1080/10942912.2017.1361969.

Quiñones-Islas N, Meza-Márquez OG, OsorioRevilla G, Gallardo-Velazquez T. 2013. Detection of adulterantsts in avocado oil by Mid-FTIR spectroscopy and multivariate analysis. Food Res Int 51: 148-154. DOI: 10.1016/j.foodres.20 12.11.037.

Rahmawati A, Kuswandi B, Retnaningtyas Y. 2015. Deteksi gelatin babi pada sampel permen lunak jelly menggunakan metode fourier transform infra red (FTIR) dan kemometrik. E- J Pustaka Kesehatan 3: 278-283. 
Rieppo L, Saarakkala S, Närhi T, Helminen HJ, Jurvelin JS, Rieppo J. 2012. Application of second derivative spectroscopy for increasing molecular specificity of fourier transform infrared spectroscopic imaging of articular cartilage. Osteoarthr Cartilage 20: 451-459. DOI: 10.101 6/j.joca.2012.01.010.

Riswahyuli Y, Rohman A, Setyabudi FMCS, Raharjo S. 2020. Indonesian wild honey authenticity analysis using attenuated total reflectancefourier transform infrared (ATR-FTIR) spectroscopy combined with multivariate statistical techniques. Heliyon 6: e03662. DOI: 10.1016/j.heli yon.2020.e03662.

Rohman A, Che Man YB, Yusof FM. 2014. The use of FTIR spectroscopy and chemometrics for rapid authentication of extra virgin olive oil. $J$ Am Oil Chem Soc 91: 207-213. DOI: 10.1007/s 11746-013-2370-5.
Rohman A, Sismindari, Erwanto Y, Che Man YB. 2011. Analysis of pork adulteration in beef meatball using fourier transform infrared (FTIR) spectroscopy. Meat Sci 88: 91-95. DOI: 10.101 6/j.meatsci.2010.12.007.

Wang J, Kliks MM, Jun S, Jackson M, Li QX. 2010. Rapid analysis of glucose, fructose, sucrose, and maltose in honeys from different geographic regions using fourier transform infrared spectroscopy and multivariate analysis. J Food Sci 75: C208-C214. DOI: 10.1111/j.1750-3841. 2009.01504.X.

Zhou J, Yao L, Li Y, Chen L, Wu L, Zhao J. 2014. Floral classification of honey using liquid chromatography-diode array detection-tandem mass spectrometry and chemometric analysis. Food Chem 145: 941-949. DOI: 10.1016/j.food chem.2013.08.117. 